\title{
PENINGKATAN KEMAMPUAN SOSIAL EMOSIONAL ANAK USIA DINI MELALUI PENGGUNAAN MEDIA ANIMASI DI TK TAQIFA BANGKINANG KOTA
}

\author{
Deddy Gusman ${ }^{1}$, Nurmalina ${ }^{2}$ \\ Program Studi Teknik Informatika ${ }^{1}$, Pendidikan Guru Pendidikan Anak Usia Dini², \\ Universitas Pahlawan Tuanku Tambusai \\ e-mail : deddyg@gmail.com
}

\begin{abstract}
Abstrak
Penelitian ini bertujuan untuk melihat peningkatan kemampuan sosial emosional anak melalui penggunaan media animasi di TK Taqifa. Penelitian ini merupakan penelitian deskriptif kualitatif, yaitu untuk menganalisis pada proses penyimpulandeduktif dan induktif mengetahui keadaan yang sebenarnya di lapangan. Hasil penelitian ini membuktikan bahwa dalam meningkatkan kemampuan social Anak guru sudah menggunakan Media Animasi sesuai dengan teori yaitu memilih tema untuk kegiatan yang ingin dicapai, menyiapkan media, memusatkan perhatian anak, menyajikan pembelajaran yang dinamis, berdasarkan prinsip-prinsip psikologi dan tingkah laku dan kognisi, memberikan kegiatan untuk merangsang kemampuan anak dan memberikan evaluasi. Akan tetapi ada beberapa kelemahan guru dalam penggunaan media animasi yaitu sulitnya guru mendapatkan video yang sesuai dengan tema pembelajaran dan kurangnya evaluasi yang diberikan guru setelah menayangkan video animasi.
\end{abstract}

Kata Kunci: sosial emosional, media animasi

\begin{abstract}
This study aims to see the improvement of children's social emotional abilities through the use of animation media in Taqifa Kindergarten. This research is a qualitative descriptive study, which is to analyze the deductive and inductive inference processes to find out the actual situation in the field. The results of this study prove that in improving children's social skills, teachers have used animated media in accordance with the theory, namely choosing a theme for the activities to be achieved, preparing media, focusing children's attention, presenting dynamic learning, based on the principles of psychology and behavior and cognition, provide activities to stimulate children's abilities and provide evaluations. However, there are several weaknesses of teachers in the use of animated media, namely the difficulty of teachers in getting videos that match the learning theme and the lack of evaluations given by the teacher after showing the animated video.
\end{abstract}

Keywords: emotional social, animated media 


\section{PENDAHULUAN}

Pendidikan Anak Usia Dini adalah suatu upaya penstimulusan dan rangsangan yang dilakukan kepada anak yang baru lahir sampai dengan usia 0-6 tahun Golden Age yang dilakukan dengan memberi rangsangan pendidikan untuk membantu pertumbuhan dan perkembangan anak, baik jasmani maupun rohani agar anak siap dalam memasuki pendidikan selanjutnya (Suyadi, 2013:18). Usia 0-6 merupakan masa emas untuk memberikan stimulus dan rangsangan kepada anak usia dini.

Anak usia dini ialah kelompok yang berada dalam proses pertumbuhan dan perkembangan yang bersifat unik yaitu pola pertumbuhan dan perkembangan, intelegensi, sosial emosional, bahasa, dan komunikasi yang khusus sesuai dengan tingkat pertumbuhan dan perkembangan anak (Fadhilla, 2016:19). Jadi dapat dipahami bahwa anak usia dini yaitu 0 sampai dengan 6 tahun yang mempunyai pola pertumbuhan dan perkembangan yang luar biasa sehingga muncul keunikan pada diri anak yang wajib distimulus dan diberi rangsangan dengan baik oleh orangtua maupun guru.

Pada dasarnya manusia terlahir kedunia ini tanpa identitas, tidak mengenal apa-apa dan siapa-siapa serta untuk apa dilahirkan. la juga dilahirkan tanpa berpesan terlebih dahulu untuk dijadikan apa, bagaimana dan mau kemana selanjutnya, kecuali hanya satu bahwa manusia dilahirkan hanya membawa fitrah yang telah dianugrahi Allah SWT (Persada, 2013: 5).

Adapun menurut ahli psikologi John Lock anak lahir bagaikan kertas putih yang belum ada gambarannya. Masa anak sering dikatakan dengan masa Golden Age, dimana perkembangan fisik, motorik, intelektual, emosional, bahasa, dan sosial berkembang sangat cepat. Priode emas ini harus diberikan perawatan yang prima untuk menjadikan anak sebagai generasi penerus yang berkualitas (Wulandari, 2014: 5).

Pada masa Golden Age anak juga sangat peka terhadap stimulus-stimulus yang dilakukan oleh lingkungan sekitar, misalnya interaksi dengan teman sebaya disekolah, orangtua dirumah, bahkan guru disekolah dengan kegiatan yang dilakukan seperti bermain sambil belajar. Karena bermain sambil belajar pada prinsipnya ada kaitannya dengan perkembangan keenam aspek salah satunya adalah sosial emosional anak. Kemampuan sosial dan emosional merupakan dua kemampuan yang berbeda, walaupun demikian kedua kemampuan atau aspek tersebut tidak dapat dipisahkan bahkan saling berkaitan satu sama lain.

Menurut Hurlock perkembangan sosial berarti perolehan kemampuan berprilaku yang sesuai dengan tuntutan sosial, anak dituntut berprilaku yang sesuai dengan aturan dan norma dalam masyarakat tempat anak berada sesuai agar anak diterima dalam masyarakat tersebut (Hurlock, 1991: 250). Sedangkan menurut Susanto perkembangan sosial merupakan proses belajar untuk menyesuaikan diri terhadap sesama kelompok, moral dan tradisi dan meleburkan diri menjadi satu kesatuan dan saling berkomunikasi dan bekerja sama (Susanto, 2012: 40).

Menurut Morgan dalam susanto menyatakan bahwa emosi dapat diartikan sebagai perasaan atau afeksi yang melibatkan kombinasi antara gejolak 
fisikologis seperti denyut jantung yang cepat dan prilaku yang tampak seperti tersenyum atau ringisan. Menurut Susanto emosi sendiri merupakan perasaan batin seseorang baik berupa pergolakan pikiran nafsu keadaan mental dan fisik yang muncul atau manifestasi kedalam bentuk-bentuk atau gejala-gejala seperti takut, marah, cemas, murung, lekas iri, cemburu, senang, kasih sayang dan ingin tahu.

Adapun kemampuan sosial emosional anak usia 5-6 tahun menurut Erik Erikson dimana pada tahap ini anak dapat berinteraksi dilingkungan sekitarnya, anak dapat bersikap kooperatif dengan teman, adanya peningkatan rasa tanggung jawab, anak dapat menyelsaikan tugas dengan percaya diri (Diane E. Papalia et al. 2010: 370).

Tidak dapat dipungkiri permasalahan dalam pendidikan anak usia dini saat ini memang ada termasuk penggunaan media dalam penyampaian materi kepada anak yang kurang efektif dan keterlibatan guru dalam mengevaluasi hasil kegiatan kurang maksimal, sehingga pemberian rangsangan atau penstimulusan enam aspek perkembangan anak usia dini sangat minim khususnya dalam aspek yang akan penulis lihat yaitu, perkembangan sosial emosional anak. Kemudian proses pembelajaran yang monoton seringkali membuat anak merasa bosan dan tidak antusias saat melakukan kegiatan sehari-hari. Penggunaa media memberikan pengaruh besar terhadap tercapainya proses pembelajaran.

Pada dasarnya anak usia dini adalah peniru, apa yang dilihat dan didengar itu lah yang mereka lakukan, jadi sebagai pendidik harus mampu memberikan ontoh yang baik. Salah satunya dengan media pembelajaran menggunakan media yang interaktif salah satunya penggunaan media animasi yang di mana didalamnya mengandung unsur-unsur edukasi yang memfokuskan kepada pengembangan sosial emosional anak.

Supaya anak menjadi lebih fokus dalam proses kegiatan dan juga mempermudah guru untuk menyampaikan ide, pesan dan membimbing anak, salah satu cara guru untuk mengatasi keadaan tersebut dengan penggunaan media dalam proses pembelajaran yang bervariasi tidak monoton. Fungsi media dalam kegiatan tersebut sebagai penyaji dan stimulus informasi (Usman dan Asnawir, 2002: 13 Menurut Hamidjojo media adalah semua bentuk perantara yang digunakan oleh manusia untuk menyampaikan atau menyebar ide, gagasan, atau pendapat yang dikemukakan itu sampai kepada penerima yang dituju (Arsyad, 2014: 3).

Banyak jenis media yang bisa digunakan oleh guru untuk penyampaian pesan pembelajaran bukan hanya menggunakan media gambar dan lain sebagainya. Menurut Bandura seseorang dapat belajar melalui pengamatan terhadap satu objek, objek harus menarik, dapat dipercaya, sesuai dengan kelompok dan memiliki standar kegunaan. Berdasarkan hal tersebut salah satu media dalam suatu kegiatan yang dapat digunakan dalam pembelajaran anak usia dini ialah media animasi. Sebuah rangkaian gambar barangkali tidak memiliki ribuan kata, namun demikian ia tiga kali lebih efektif dibandingkan katakata gambar-gambar dan kata-kata saja. Ketika proses kegiatan menggunakan dimensi audio dan visual, pesan yang diberikan akan menjadi lebih bermanfaat dan bermakna berkat sistem penyampaian tersebut (Silberman, 2013: 25) 
Pemanfaatan media animasi dapat digunakan oleh guru untuk mengenalkan kepada anak tentang aspek sosial emosional. Media animasi menjadi suatu yang menarik jika dijadikan pedoman bagi pengajar pada umumnya, terutama pengenalan sosial emosional yang membutuhkan sebuah cerita pendek yang dikemas menjadi rangkaian animasi bergerak. Kemudian yang merasa kesulitan dalam mencari media yang tepat untuk menyampaikan meteri dalam menciptakan suasana menarik dan tidak membosankan bagi anak. Data pengamatan awal yang dilakukan penulis pada tanggal 15 September 2016 diketahui jumlah peserta didik kelompok B2 di Taman Kanak Kanak Aftihu Jannah sebagai berjumlah 13 anak yang terdiri dari 8 laki-laki dan 5 perempuan.

Dari pengamatan yang penulis lakukan bahwa guru telah menggunakan media animasi dalam kegiatan khususnya dalam mengenalkan aspek sosial emosional tetapi dari hasil observasi menunjukan bahwasanya masih ada beberapa anak yang kemampuan sosial emosionalnya belum berkembang secara optimal terlihat dari anak yang kurang bermain bersama anak-anak lain dilingkungan sekitarnya, kurangnya bersikap kooperatif dengan teman, kurangnya rasa bertanggung jawab, belum memiliki kepercayaan diri yang tinggi dan dilihat dari keadaan anak yang pada dasarnya, tidak suka terikat, belum suka pelajaran, belum bisa menjalankan kewajiban-kewajiaban, merasa bosan dengan kegiatan pembelajaran karena monoton, anak hanya ingin bermain dan membuang-buang waktu. Sedangkan guru sudah mengenalkan kegiatan menggunakan media yang interaktif Hasil Observasi TK Taqifa Bangkinang Kota. Berdasarkan uraian di atas, penulis ingin melakukan suatu penelitian tentang "Peningkatan Kemampuan Sosial Emosional Anak Usia Dini melalui Penggunaan Media Animasi di TK Taqifa Bangkinang Kota".

\section{METODE}

Penelitian ini menggunakan pendekatan penelitian yang berupa deskriptif kualitatif. Pendekatan yang akan digunakan penulis dalam penelitian ini adalah pendekatan kualitatif deskriptif. Karena penelitian ini lebih menekankan analisisnya pada proses penyimpulan deduktif dan induktif serta analisis terhadapdinamika hubungan antar fenomena yang diamati, dengan menggunakan logika ilmiah (Moleong, 2011).

Kemudian penelitian ini merupakan penelitian deskriptif, yaitu penelitian yang dimaksudkan untuk mengumpulkan informasi mengenai status suatu gejala yang ada, yaitu keadaan gejala menurut apa adanya pada saat penelitian dilakukan (Arikunto, 2007: 234). Dimana penelitian ini untuk mengetahui keadaan sebenarnya yang terjadi dilapangan atau ditempat penulis melakukan penelitian dengan menjabarkan data yang penulis peroleh di tempat penelitian berlangsung. 


\section{HASIL PEMBAHASAN}

\section{Hasil}

\section{Penggunaan Media Animasi Dalam Meningkatkan Kemampuan Sosial Emosional Anak Usia Dini}

Berdasarkan hasil observasi pada tanggal 17 Maret sampai dengan 17 Mei 2017 TK Taqifa Bangkinang Kota, maka dapat diketahui bahwa media animasi yang digunakan guru dalam kegiatan mengenalkan kemampuan sosial emosional anak. Untuk mengetahui lebih lanjut bagaimana penggunaan media dalam meningkatkan kemampuan sosial emosional anak TK Taqifa Bangkinang Kota.

a. Guru memilih tema untuk kegiatan yang ingin dicapai

Upaya guru dalam menciptakan suatu sistem lingkungan yang memungkinkan terjadinya proses kegiatan pembelajaran merupakan suatu keharusan, dengan maksud agar tujuan pembelajaran dapat dicapai secara optimal, oleh karena itu guru di tuntut untuk menyusun rencana kegiatan harian. Hasil observasi yang penulis lakukan dari tanggal 27 Maret 2017 bahwasanya sebelum guru melakukan kegiatan terlebih dahulu menyiapkan RPPH agar dapat tercapainnya tujuan pembelajaran.

b. Guru Menyiapkan Media

Adapun dari hasil observasi yang dilakukan pada tanggal 27 Maret di Taman Kanak-Kanak Aftihu Jannah Sukarame Bandar Lampung, sebelum kegiatan berlangsung guru menyiapakan media penujang seperti laptop, proyektor, spiker dan media penunjang lainnya terlihat dari kelengkapan media walaupun tidak lengkap akan tetapi penggunaan media pembelajaran tetap berjalan dengan baik.

c. Guru memusatkan perhatian anak

Berdasarkan hasil observasi pada tanggal 27 Maret 2017, guru dalam menampilkan media dimulai dari menghidupkan laptop, menghidupkan LCD dan menyambungkannya dengan laptop. Dikegiatan awal guru menyampaikan apa tujuan dari materi yang akan ditayangkan. Sebelum kegiatan berlangsung guru mencoba untuk memusatkan perhatian anak agar anak tertuju kedepan diisi dengan bercerita dan Tanya jawab, yang mengantarkan anak sekolah siapa, sudah sarapan atau belum hal tersebut cara guru untuk memusatkan perhatian anak. Kemudian terlihat dari cara guru mengatur posisi tempat duduk anak berhadapan dengan papan tulis yang menjadi letak patulan dari proyektor dan bagaimana mengoprasikan media tersebut agar lebih kondusif.

d. Guru menyajikan pembelajaran yang dinamis

Berdasarkan hasil observasi pada tanggal 30 Maret 2017 bahwa guru dalam menyajikan media untuk ditampilkan ketika pembelajaran sesuai dengan media animasi yang terbaru dan sesuai materi yaitu pengenalan tentang aspek sosial emosional. Guru menggunakan media animasi dengan menampilkan video animasi tentang bertanggung jawab, dan guru juga menggunakan metode demonstrasi. Pada saat menayangkan video animasi dengan mengenalkan indikator dari kemampuan sosial 
emosioanal yang berdurasi 5 sampai dengan 8 menit, di akhir dengan guru bertanya kepada anak mengenai tayang yang telah di tonton.

e. Guru menyajikan berdasarkan prinsip-prinsip psikologi dan tingkah laku dan kognisi

Penggunaan media animasi yang guru gunakan harus berdasarkan prinsip-prinsip psikologi dan tingkah laku dan kognisi. Cuplikan video yang akan ditayangkan apakah sesuai dengan prinsip-prinsip psikologi, tingkah laku, dan kognisi dan harus benar-benar sesuai untuk di tayangkan kepada anak. Berdasarkan hasil observasi tanggal 03 April 2021 media animasi yang guru gunakan sudah berdasarkan prinsip-prinsip psikologi dan tingkah laku dan kognisi. Guru dalam menampilkan media dimulai dengan memilih video animasi yang layak untuk di tonton oleh anak usia dini dan memiliki nilai edukasi dan tidak ada unsur pornografi. Kemudian dari ketiga indikator penggunaan tersebut bahwasanya guru menggunakan media animasi sudah cukup baik.

f. Guru memberikan kegiatan yang merangsang kemampuan anak

Untuk melihat kemampuan sosial emosional anak guru memberikan kegiatan yang dapat merangsang kemampuan tersebut dilihat dari kegiatan anak setelah melihat tayangan animasi. Dari hasil Observasi yang penulis lakukan 03 April 2021 guru memberikan kegiatan seperti memberikan tugas melipat, mengkolase, mewarnai untuk melihat apakah anak dapat menyelsaikan sampai selesai, kemudian membuat permainan estapet karet menggunakan pipet untuk melihat interaksi anak, kerjasama anak, perasaan anak dengan teman yang lain.

\section{Faktor-Faktor Yang Mempengaruhi Pelaksanaan Penggunaan Media Animasi Dalam Meningkatkan Kemampuan Sosial Emosional Anak Taman Kanak-Kanak Aftihu Jannah}

a. Mempermudah guru untuk menyampaikan informasi dan pesan kepada anak

guru sangat besar semangat dan keinginan guru dan anak dalam mengusahakan penggunan media pembelajaran animasi dalam menyampaikan informasi dan pesan. Dengan menggunakan media ini, selain menyenagkan bagi anak guru juga lebih mudah dan efektif dalam menyampaikan pesan kepada anak. Hal ini sesuai dengan faktor-faktor yang mempengaruhi penggunaan media animasi menurut Sadiman bahwasanya mempermudah guru untuk menyampaikan informasi dan pesan kepada anak.

b. Dapat memunculkan rasa ingin tahu anak pada informasi yang disampaikan oleh guru. Media animasi dalam pemanfaatannya dapat menarik perhatian anak dan keingintahuan anak. Hal ini karena media pembelajaran tersebut lebih menarik.

c. Dari pernyataan-pernyataan tersebut di atas dapat diketahui bahwa media pembelajaran animasi dapat menarik perhatian,minat anak dan pada saat video animasi ditayangkan berbagai macam respon anak yang terlihat ada anak yang tertawa, senang dan ada juga anak yang biasa-biasa saja, tapi lebih banyak anak yang senang menggunakan media ini. sehingga proses kegiatan tersebut dapat menimbulkan keingintahuan anak lebih besar lagi dan diharapkan mampu meningkatkan kemampuan anak khususnya dalam 
kemampuan sosial emosional yang penulis teliti. Hal ini sesuai dengan faktor-faktor yang mempengaruhi pelaksanaan penggunaan media menurutSadiman yaitu dapat memunculkan rasa ingin tahu anak pada informasi yang disampaikan oleh guru.

d. Sesuai dengan tujuan yang ingin dicapai

Media dipilih berdasarkan tujuan yang telah ditetapkan yang secara umum mengacu kepada salah satu pengenalan kemampuan anak yaitu kemampuan sosial emosional. Media animasi di Taman kanak-kanak Aftihu Jannah dalam proses kegiatan yang dilakukan diharapkan mempermudah dan dapat mencapai tujuan yang akan dicapai oleh guru dalam menyampaikan atau menganalkan materi sehingga kemampuan sosial emosional anak dapat terstimulus dengan baik.

\section{Pembahasan}

\section{Penggunaan Media Animasi Dalam Meningkatkan Kemampuan Sosial Emosional Anak Usia Dini}

Upaya guru dalam menciptakan suatu sistem lingkungan yang memungkinkan terjadinya proses kegiatan merupakan suatu keharusan, dengan maksud agar tujuan kegiatan dikelas dapat dicapai secara optimal, oleh karena itu guru di tuntut untuk menyusun rencana kegiatan harian. Bahwasannya guru di Taman Kanak-Kanah Aftihu Jannah sebelum melakukan kegiatan telebih dulu menyusun rencana pembelajaran harian.Walaupun sedikit sulit menggunaka video animasi yang sesuai dengan tema.

sebelum kegiatan berlangsung guru di Taman Kanak-kanak Aftihu Jannah menyiapakan media penujang seperti laptop, proyektor, spiker dan media penunjang lainnya terlihat dari kelengkapan media walaupun tidak lengkap akan tetapi penggunaan media pembelajaran tetap berjalan dengan baik. Guru di Taman Kanak-kanak selalu menyiapkan media dengan semaksimal mereka sebelum anak-anak tiba di sekolah.

Sebelum kegiatan berlangsung guru mencoba untuk memusatkan perhatian anak agar anak tertuju kedepan diisi dengan bercerita dan Tanya jawab, yang mengantarkan anak sekolah siapa, sudah sarapan atau belum hal tersebut cara guru untuk memusatkan perhatian anak. Kemudian terlihat dari cara guru mengatur posisi tempat duduk anak berhadapan dengan papan tulis yang menjadi letak patulan dari proyektor.

Penggunaan media animasi dengan memberikan tayang-tayang video yang terbaru yang dilakukan guru memberikan posisi yang strategis dimana di dalamnya akan menarik perhatian anak atau dapat dikatakan dapat mengendalikan perhatian anak yang membuat anak tertarik dan antusias pada saat proses kegiatan berlangsung. Jika anak memiliki daya tarik dalam proses kegitan maka anak tersebut akan mampu memahami maksud materi yang disampaikan oleh guru melalui media animasi.

Penggunaan media animasi yang guru gunakan berdasarkan prinsipprinsip psikologi dan tingkah laku dan kognisi. Cuplikan video yang akan ditayangkan apakah sesuai dengan prinsip-prinsip psikologi, tingkah laku, dan 
kognisi dan harus benar-benar sesuai untuk di tayangkan kepada anak dan tidak mengandung unsur yang menyimpang.

\section{Faktor-Faktor Yang Mempengaruhi Pelaksanaan Penggunaan Media Animasi Dalam Meningkatkan Kemampuan Sosial Emosional Anak Usia Dini TK Taqifa}

a. Mempermudah guru untuk menyampaikan informasi dan pesan kepada anak

Besarnya keinginan guru untuk memanfaatkan media pembelajaran intaraktif. Guru dalam pengajarannya memanfaatkan animasi dalam mengenalkan atau menyampaikan materi kepada peserta didik karena selain media yang praktis, media animasi juga merupakan media interaktif yang dari beberapa penelitian dapat meningkatkan kemampuan anak.

b. Dapat memunculkan rasa ingin tahu anak pada informasi yang disampaikan oleh guru

Media animasi dalam pemanfaatannya dapat memudahkan untuk pengajaran atau penyajian materi. Hal ini karena media pembelajaran tersebut lebih menarik. Dapat diketahui bahwa media pembelajran animasi dapat menarik perhatian dan minat anak, sehingga pembelajaran tersebut diharapkan mampu meningkatkan kemampuan anak khususnya dalam kemampuan sosial emosional anak.

c. Sesuai dengan tujuan yang ingin dicapai

Media yang digunakan sesuai dengan tujuan yang ingin dicapai. Dengan menggunakan media animasi guru berharap dalam menyampaikan materi dengan mengenalkan kemampuan sosial emosional menggunakan media bantu video animasi yang berdurasi pendek mampu menstimulasi perkembangan sosial emosional. Dalam proses kegiatan diharapkan dapat mencapai tujuan yang akan dicapai oleh seorang guru dalam menyampaikan atau mengenalkan materi sehingga kemampuan sosial emosional anak dapat terstimulus dengan tepat.

d. Ketersediaan media disekolah

Ketersedian peralatan yang mendukung penggunaan media turut memberikan pengaruh terhadap pelaksanaan guru dalam menggunakan media animasi dalam meningkatkan kemampuan anak khususnya sosial emosional. Apabila guru mampu menggunakan media animasi akan tetapi tidak didukung dengan adanya perlengkapan yang memadai dalam menggunakan media tersebut maka tidak akan berjalan dengan baik. Kelengkapan media yang ada di Taman Kanak-Kanak Aftihu Jannah cukup memadai walaupun tidak sepenuhnya lengkap, masih ada beberapa peralatan dan video yang kurang lengkap, akan tetapi penggunaan media animasi tetap berjalan dalam meningkatkan kemampuan anak khususnya sosial emosional anak.

\section{KESIMPULAN}

Berdasarkan hasil analisis dan pembahasan yang penulis lakukan dapat disimpulkan menganai Penggunaan Media Animasi Dalam Meningkatkan Kemampuan Anak Usia Dini Kelompok B2 Taman Kanak-kanak Aftihu Jannah Sukarame Bandar Lampung bahwa guru sudah menggunakan Media Animasi 
sesuai dengan teori yaitu memilih tema untuk kegiatan yang ingin dicapai, menyiapkan media, memusatkan perhatian anak, menyajikan pembelajaran yang dinamis, berdasarkan prinsip-prinsip psikologi dan tingkah laku dan kognisi, memberikan kegiatan untuk merangsang kemampuan anak dan memberikan evaluasi. Akan tetapi ada beberapa kelemahan guru dalam penggunaan media animasi yaitu sulitnya guru mendapatkan video yang sesuai dengan tema pembelajaran dan kurangnya evaluasi yang diberikan guru setelah menayangkan video animasi.

Kemudian faktor-faktor yang mempengaruhi pelaksanaan penggunaan media animasi di Taman Kanak-Kanak Aftihu Jannah antara lain mempermudah guru dalam menyampaikan pesan kepada anak, dapat memuculkan atau menarik perhatian anak terhadap pesan yang disampaikan oleh guru, sesuai dengan tujuan yang ingin dicapai oleh guru dan ketersediaan media yang ada di Taman Kanak Kanak Taqifa Bangkinang Kota.

\section{DAFTAR PUSTAKA}

Al-Uqshari, Yusuf. 2006. Menuju Puncak Prestasi Tanpa Batas, alih bahasa, Abdul Hayyie al Kattani. Jakarta: Gema Insani.

Anitah, S. 2010. Media Pembelajaran. Surakarta: Yuma Pustaka.

Arikunto, Suharsimi. 2007. Manajemen Penelitian. Jakarta: Rieneka Cipta.

Arsyad, Azhar . Op. Cit., mengutip Kemp, J.E. dan Dautn, D.K. Planning and Producing Instrutional Media (New York: Harper \& Row, Publishers, 1985), h. 3 et seqq.

Arsyad, Azhar. 2014. Media Pembelajaran. Jakarta: Raja Grafindo Persada.

Asustian, Ary Ginanjar. 2003. ESQ Power Sebuah Inner Jouney melalui Al Ihsan. Jakarta: Arga.

Cooper, Robert, K. dan Ayman Sawaf. 2000. Executive EQ, Kecerdasan Emosional dalam Kepemimpinan dan Organisasi, cet. Ke-3. Jakarta: Gramedia Pustaka Utama Jakarta.

Daryanto. 2010. Media Pembelajaran. Bandung: Satu Nusa.

Fadillah, Muhammad. 2016. Desain Pembelajaran Pendidikan Anak Usia Dini. Yogyakarta: Arus Media.

Hurlock. 1991. Perkembangan Anak. Jakarta: Erlangga.

Ibrahim, R. dan Nana Syaodih S. 2004. Perencanaan Pengajaran. Jakarta: Asdi Mahasatya.

Indrijati, Herdina. 2006. Psikologi Perkembangan dan Pendidikan Anak Usia Dini. Jakarta : Prenadamedia.

Mashar, Riana. 2011. Emosi Anak Usia Dini dan Stategi Pengembangannya Jakarta: Kencana.

Miarso, Yusufhadi. Loc. Cit., mengutip The Commission of Instructional Technology Report, to Improve Learning. New York: R.R. Bowker Co, 1970.

Moleong, Lexy J. 2011. Metodologi Penelitian Kualitatif. Bandung: Remaja Rosdakarya.

Papalia, Diane E. et al, 2010. Human Development. Jakarta: Kencana Prenada Media Group.

Purnama, B.E. 2013. Konsep Dasar Multimedia. Yogyakarta: Graha IImu. 
Ramattullah, Muhammad. Pengaruh Pemanfaatan media pembelajaran animasi terhadap hasil belajar pada mata pelajaran IPS Siswa Kelas VII SMPN 6 Banjarmasin" (On-Line), Tersedia di: http://www.academia.edu/download/31933424/17uhammad_Rahmattullah_2.pdf (24 Desember 2016).

Rosyadi, H.A. Rahmat. 2013. Pendidikan Islam Dalam Pembentukan Karakter Anak Usia Dini. Jakarta: Raja Grafindo Persada.

Rusman, et all. 2015. Pembelajaran Berbasis Tekhnologi Informasi dan Komunikasi. Jakarta: Raja Grafindo.

Sadiman, Arief S. et al,. 2012. Media Pendidikan, Pengertian, Pengembangan, dan Pemanfaatannya. Jakarta: Raja Grafindo Persada.

Saefullah, K. H. U. 2012. Psikologi perkembangan dan Pendidikan. Bandung: Pustaka Setia.

Sanaky, Hujair AH. 2011. Media Pembelajaran. Yogyakarta: Kaukaba.

Silberman, Melvin L. 2013. Active Learning. 101 Cara Belajar Siswa Aktif, penerjemah: Raisul Muttaqien. Bandung: Nusamedia.

Suheri, A. "Animasi Multimedia Pembelajaran". (On-Line) Diperoleh dari : http://ashiriesuci.com/ animasi multimedia pembelajaran. (25 Desember 2016.

Susanto, Ahmad. 2012. Perkembangan Anak Usia Dini: pengantar dalam berbagai aspeknya. Jakarta: Kencana Pranda Media Group.

Suyadi, Maulidya. 2013. Konsep Dasar PAUD. Bandung : Rosdakarya.

Uno, Hamzah, B. dan Nina Lamatenggo. 2011. Tekhnologi Komunikasi \& Informasi pembelajaran. Jakarta: Bumi Aksara.

Usman, M. Basyiruddin dan Asnawir. 2002. Media Pemebelajaran. Jakarta: Delia Citra Utama.

Wulandari, Heny. 2014. Kesehatan dan Gizi Untuk Anak Usia Dini. Lampung: IAIN Raden Intan.

Yurdik. 2012. Psikologi Perkembangan. Jakarta: Kecana Media Group.

Yusuf, Syamsu. 2011. Psikologi Perkembangan Anak dan Remaja. Bandung: Remaja Rosdakarya. 